\title{
POWER SUPPLY INVERTER DC-DC SEBAGAI SUPPLY AUDIO AMPLIFIER
}

\author{
Ilham Setiya Wardani, Saiful Manan \\ Program Studi Diploma III Teknik Elektro \\ Sekolah Vokasi Universitas Diponegoro
}

\begin{abstract}
Ilham Setiya Wardani, Saiful Manan in this paper explain that Utilization of power electronics components in the process of conversion of electrical energy has been growing from year to year. for controlling power from one form to another is very important and the characteristics of the equipment of power electronics has allowed it. DC-DC converters can also be called a wave DC inverter capable of producing symmetrical widely used and applied in industry and everyday life.In the inverter power supply are made using half-bridge converter topology. Half-bridge converter topology has several advantages that are easy to create and output a lot easier in the controlling. The process of switching at the half bridge converter using mosfet IRFZ44N and executed using ICTL494.In the design of the tool, using the supply is 12 Volt DC that directly goes to IC TL494 and frequency output that is generated directly toward the driver mosfet with the type BC327 used to mesaklarkan mosfet by means of on / off alternately to supply the power transformer intiferit to raise the voltage to 26 volt AC that will be rectified by using fast diode recofery MUR1560 to rectify the AC into DC voltage with the output voltage of +/26 volts $D C$.
\end{abstract}

Keywords: power supply, inverter, TL494

\section{PENDAHULUAN \\ Latar Belakang}

Pemanfaatan komponen elektronika daya di dalam proses konversi energi listrik telah semakin berkembang dari tahun ke tahun. untuk pengendalian daya dari satu bentuk ke bentuk yang lain menjadi sangat penting dan karakteristik dari peralatanperalatan elektronika daya telah memungkinkan hal tersebut. konverter DC-DC dapat disebut juga inverter mampu menghasilkan gelombang DC simetris yang banyak digunakan dan diaplikasikan dalam industri dan kehidupan sehari-hari. Elektronika daya mulai populer setelah berbagai pengaturan secara konvensional kurang dapat memenuhi kebutuhan industri. Pengaturan berbagai aplikasi di industri secara konvensional tidak efektif dan menimbulkan rugi-rugi cukup besar sehingga diperlukan mekanisme pengaturan yang lebih baik. Seperti halnya dengan power supply yang dahulu banyak digunakan yaitu power supply konvensional. Dimana power supply konvensional ini memiliki beberapa kelemahan yaitu memiliki efisiensi yang rendah karena mengambil tegangan dari hasil penyearahan sinyal sinus. Untuk meningkatkan efisiensi power supply maka sinyal yang disearahkan harus berupa sinyal kotak. Dalam hal ini kemudian muncul sebuah power supply sistem baru dengan metode pensaklaran yang disebut sistem switching. Beberapa perangkat pendukung mengalami perkembangan ditambah lagi alat-alat elektronika yang semakin beragam. Salah satu sistem elektronika yang dikenal adalah inverter berfungsi mengubah tegangan DC menjadi tegangan AC. Inverter ini berfungsi sebagai sumber energi penyedia listrik cadangan baik misalnya dikendaraan, maupun di rumah atau sebagai emergency power saat aliran listrik rumah padam.Berdasar pokok pembahasan tersebut penulis mempunyai suatu gagasan atau ide untuk merancang sebuah sumber energi. yaitu penulis membuat sebuah realisasi proyek tugas akhir, yang berjudul " Power supply Inverter dc to dc sebagai supply audio amplifier".

\section{Batasan Masalah}

Pada penelitian ini masalah dibatasi pada halhal, diantaranya sebagai berikut :

- Tegangan sumber sebesar 12 Volt DC.

- Membutuhkan tegangan outputan DC +/- 26 volt.

- Mengetahui cara kerja power supply inverter DC-DC

- Komponen elektronika yang dibahas hanya pada fungsi kerjanya.

\section{LANDASAN TEORI}

\section{Sumber Daya}

Power supply merupakan salah satu sumber daya listrik yang digunakan untuk mensuplai peralatan elektronik yang membutuhkan tegangan DC (Direct Current). Power supply didapat dari hasil penyerahan arus bolak-balik AC (Alternating Current) yang bersumber dari tegangan jala-jala 220 VAC. Hasil penyerahan power supply ini masih banyak ripple, sehingga catu daya DC yang paling baik adalah baterai.

\section{Inverter}

Inverter adalah Rangkaian elektronika daya yang digunakan untuk mengkonversikan tegangan searah (DC) ke suatu tegangan bolak-balik (AC). Ada beberapa topologi inverter yang ada sekarang ini, dari yang hanya menghasilkan tegangan keluaran kotak 
bolak-balik (push-pull inverter) sampai yang sudah bisa

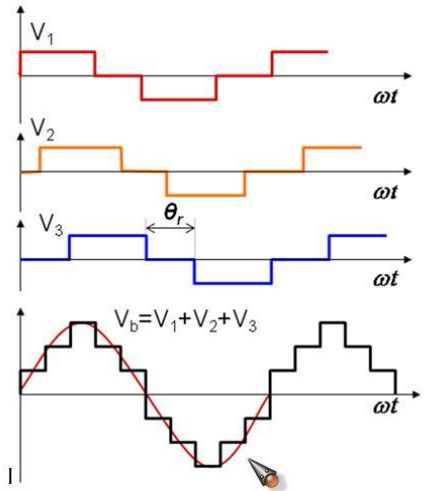

Gambar 1. Bentuk gelombang inverter menghasilkan tegangan sinus murni (tanpa harmonisa).

Inverter satu fasa, tiga fasa sampai dengan multifasa dan ada juga yang namanya inverter multilevel (kapasitor split, diode clamped dan susunan kaskade).

\section{Mosfet}

MOSFET (Metal Oxide Semiconductor Field Effect Transistor) adalah suatu transistor dari bahan semikonduktor (silikon) dengan tingkat konsentrasi ketidakmurnian tertentu. Tingkat dari ketidakmurnian ini akan menentukan jenis transistor tersebut, yaitu transistor MOSFET tipe-N (NMOS) dan transistor MOSFET tipe-P (PMOS). Bahan silicon digunakan sebagai landasan (substrat) dari penguras (drain), sumber (source), dan gerbang (gate). Selanjutnya transistor dibuat sedemikian rupa agar antara substrat dan gerbangnya dibatasi oleh oksida silikon yang sangat tipis. Oksida ini diendapkan di atas sisi kiri dari kanal, sehingga transistor MOSFET akan mempunyai kelebihan dibanding dengan transistor BJT (Bipolar Junction Transistor), yaitu menghasilkan disipasi daya yang rendah. Gambar menunjukan konfigurasi dasar MOSFET, yang terdiri atas gate, drain, dan source. Adapun prinsip kerja dari MOSFET adalah sebagai berikut:

- Untuk tipe NPN, ketika gate diberi tegangan positif, maka molekul elektron dari semikonduktor $\mathrm{N}$ dari drain dan source tertarik oleh gate menuju semikonduktor tipe $\mathrm{P}$ yang berada diantaranya. Dengan adanya elektronelektron ini pada semikonduktor $\mathrm{P}$, maka akan menjadi suatu jembatan yang memungkinkan pergerakan elektron dari source ke drain.
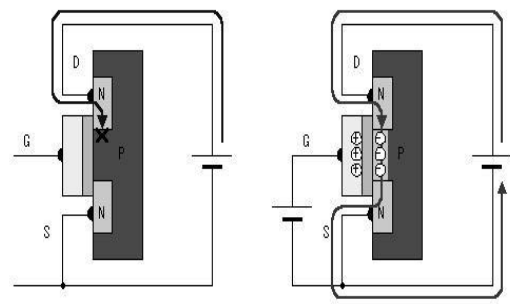

Gambar 2 Konfigurasi dasar MOSFET
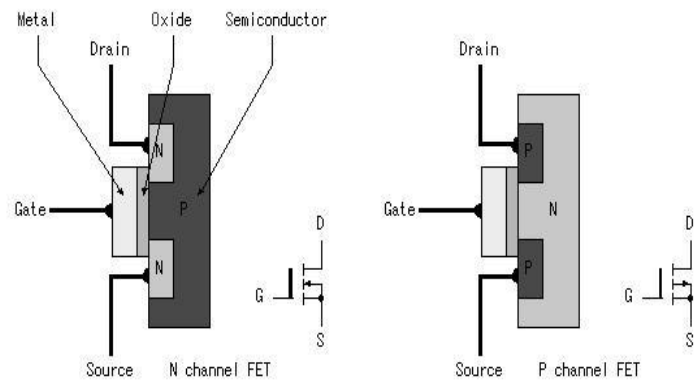

Gambar 3 Prinsip kerja MOSFET tipe NPN

- Untuk tipe PNP, prinsip kerjanya sama hanya saja tegangan yang diberikan pada gate berkebalikan dengan MOSFET tipe NPN. Ketika tegangan negatif diberikan ke gate, hole dari semikonduktor tipe $\mathrm{P}$ dari source dan drain tertarik ke semikonduktor tipe $\mathrm{N}$ yang beradadiantaranya. Dengan adanya jembatan hole ini maka arus listrik dapat mengalir dari source ke drain.
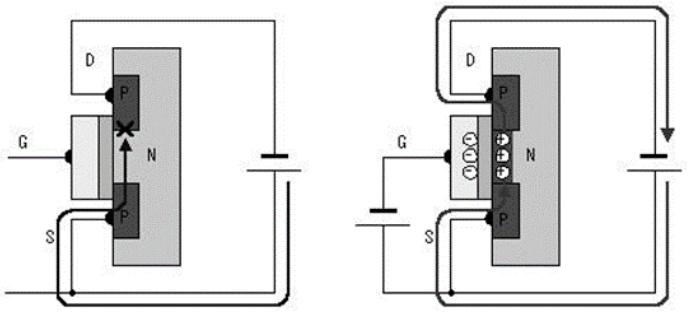

Gambar 4. Prinsip kerja MOSFET PNP

\section{Accumulator}

Aki adalah sebuah alat yang dapat menyimpan energi (umumnya energi listrik) dalam bentuk energi kimia. Di dalam standar internasional, setiap satu cell akumulator memiliki tegangan sebesar 2 volt. Sehingga aki 12 volt memiliki 6 cell sedangkan aki 24 volt memiliki 12 cell. Secara sederhana aki merupakan sel yang terdiri dari elektrode $\mathrm{Pb}$ sebagai anode dan $\mathrm{PbO} 2$ sebagai katode dengan elektrolit $\mathrm{H} 2 \mathrm{SO} 4$.

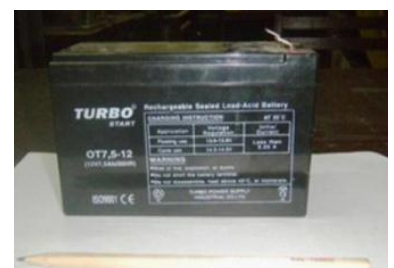

Gambar 5. Aki (Budhi, etall., 2014)

Untuk mengetahui waktu dalam proses pengisian aki, dapat menggunakan perhitungan dibawah ini:

$$
\begin{aligned}
& \mathrm{Ta}=\frac{A h}{A} \ldots \ldots . . . . . . . . . \\
& \text { (Iswandi, 2013) }
\end{aligned}
$$

Keterangan :

$\mathrm{Ta}=$ Lamanya pengisisan arus (jam)

$\mathrm{Ah}=\mathrm{Besarnya}$ kapasitas aki (Ampere hours)

$\mathrm{A}=$ Besarnya arus pengisisan ke aki (Ampere) 


\section{Transformator}

Transformator merupakan suatu komponen penting dalam sebuah konversi tegangan.Transformator biasa digunakan dalam system tenaga listrik. Transformator biasa digunakan untuk merubah atau meneruskan besaran listrik ac dari suatu rangkaian kerangkaian lain melalui gandengan elektro magnetic dengan prinsip induksi dengan besar frekuensi yang sama.

Transformator terdiri dari tiga bagian penting yaitu:

1. Kumparan primer

2. KumparanSekunder

3. Inti trafo

Transformator pada frekuensi tinggi digunakan inti ferit yang dianggap lebih efektif karena tidak meninggalkan medan magnet, sehingga energi dari kumparan primer langsung ditransfer menuju kumparan sekunder.

\section{PWM}

Pulse Width Modulation (PWM) secara umum adalah sebuah cara memanipulasi lebar sinyal yang dinyatakan dengan pulsa dalam suatu perioda, untuk mendapatkan tegangan rata-rata yang berbeda. Beberapa Contoh aplikasi PWM adalah pemodulasian data untuk telekomunikasi, pengontrolan daya atau tegangan yang masuk ke beban, regulator tegangan, audio effect dan penguatan, serta aplikasi-aplikasi lainnya.

Sinyal PWM pada umumnya memiliki amplitudo dan frekuensi dasar yang tetap, namun memiliki lebar pulsa yang bervariasi. Lebar Pulsa PWM berbanding lurus dengan amplitudo sinyal asli yang belum termodulasi. Artinya, Sinyal PWM memiliki frekuensi gelombang yang tetap namun duty cycle bervariasi (antara 0\% hingga 100\%).

Pada apliaksi power supply switching ini, PWM digunakan untuk memberikan sinyal input MOSFET agar bekerja secara bergantian. Lebar duty-cycle untuk menentukan tegangan keluaran.

\section{PERANCANGAN ALAT \\ Diagram blok}

Diagram perancangan alat ini diperlihatkan pada Gambar 6. berikut

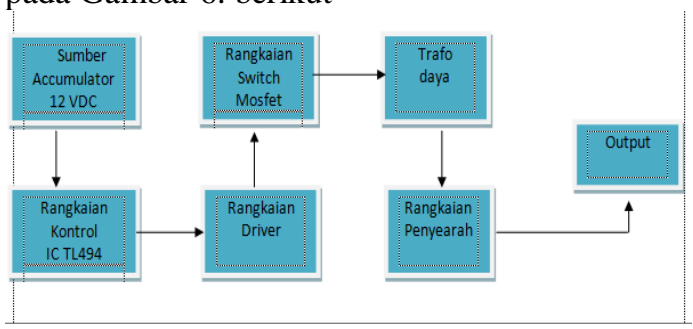

Gambar 6. Diagram Blok Alat

Sumber input yang digunakan pada power supply Inverter berasal dari accumulator mobil dengan tegangan 0 Volt sampai 12 Volt DC. di dalam baterai dapat berlangsung proses pengubahan kimia menjadi tenaga listrik (proses pengosongan), dan sebaliknya dari tenaga listrik menjadi tenaga kimia, pengisian kembali dengan cara regenerasi dari elektroda-elektroda yang dipakai, yaitu dengan melewatkan arus listrik dalam arah (polaritas) yang berlawanan di dalam sel. Baterai atau aki pada mobil berfungsi untuk menyimpan energi listrik dalam bentuk energi kimia, yang akan digunakan untuk mensuplai (menyediakan) listik ke sistem yang ditentukan pada rangkaian alat tugas akhir yang dibuat.

\section{Rangkaian Kontrol}

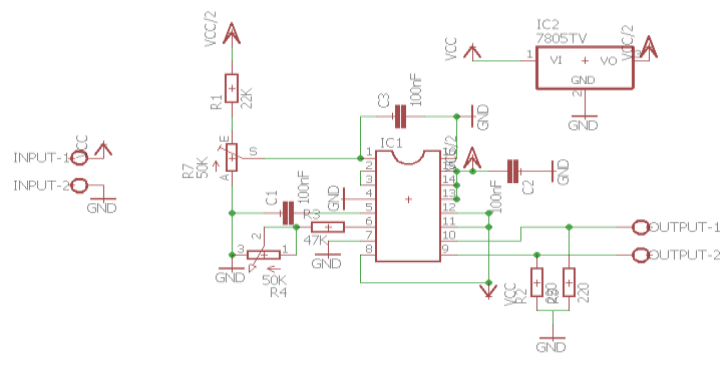

Gambar 7. Rangkaian Kontrol

Rangkaian pembangkit PWM yang digunakan pada perancangan power supply ini yaitu IC TL494, pembangkit PWM ini yang nantinya akan menentukan MOSFET (M1) on, MOSFET (M2) off ataupun sebaliknya MOSFET (M2) on, MOSFET (M1) off yang nantinya hasil dari pensaklaran ini akan menghasilkan arus bolak-balik yang mengalir pada trafo daya, untuk proses konversi tegangan. Rangkaian pembangkit PWM ini terdiri dari IC TL494, resistor, dan kapasitor. Berikut adalah cara kerja pembangkitan gelombang pulsa menggunakan IC TL494. merupakan IC pembangkit gelombang pulsa yang memiliki 2 buah output yang berlawanan, yaitu terletak pada pin 9 sebagai output A dan pin 10 sebagai output B. IC ini memiliki 1 buah inputan pada pin 12 dicatu dengan tegangan catu yang sama. Adapun groundingnya terletak pada pin 7 . Untuk menghasilkan osilasi frekuensi yang nantinya akan membentuk gelombang kotak maka perlu menentukan nilai-nilai komponen pada RT dan CT pada pin 5 dan pin 6 . Pada perancangan alat ini menggunakan frekuensi $96 \mathrm{KHz}$. Untuk memperoleh frekuensi switching $96 \mathrm{KHz}$ dengan menentukan nilai RT dan CT dengan menggunakan persamaan sebagai berikut:

$$
\text { focs }=\frac{1.1}{R_{T} C_{T}}
$$

Dimana focs $=$ frekuensi osilasi

$$
\mathrm{C}_{\mathrm{T}} \quad=\text { kapasitor pencacah }
$$$$
\mathrm{R}_{\mathrm{T}} \quad=\text { resistor pencacah }
$$

Sehingga didapat frekuensi osilasi sebagai berikut jika ditentukan $\mathrm{R}=47 \mathrm{k}$ ohm, dan $\mathrm{C}_{\mathrm{T}}=22 \mathrm{n}$ Farad, maka: 


$$
\begin{aligned}
\text { focs } & =\frac{1.1}{R_{T} \cdot C_{T}} \\
\text { focs } & =\frac{1.1}{47 K .22 n f} \\
\text { focs } & =\frac{1.1}{(1,034,000)} \\
\text { focs } & =94,000 \mathrm{~Hz}
\end{aligned}
$$

Frekuensi switching $94 \mathrm{KHz}$ tersebut digunakan untuk mensaklar MOSFET, sehingga MOSFET akan berada dalam kondisi ON dan OFF sebanyak 94,00 ribu kali dalam satu detik. Frekuensi switching 94 $\mathrm{KHz}$ tersebut digunakan untuk mensaklar MOSFET, sehingga MOSFET akan berada dalam kondisi ON dan OFF sebanyak 39,47 ribu kali dalam satu detik

\section{Rangkaian Driver MOSFET}

Rangkaian driver MOSFET digunakan untuk menggerak pensaklaran MOSFET. Pada tugas akhir ini rangkaian driver berfungsi sebagai penguatan sinyal output dari TL494 dan sebagai proteksi rangkaian kontrol. Rangkaian driver terdiri atas kombinasi dua transistor PNP yang disusun secara half bridge. Transistor yang digunakan yaitu BC327 Rangkaian driver MOSFET ini membutuhkan suplai tegangan 12 Volt DC untuk dapat bekerja. Kombinasi transistor yang digunakan untuk penguatan sinyal output dari TL494 dengan cara melakukan pensaklaran secara bergantian. Ketika sinyal output A memberikan memberikan perintah on maka, T1 akan on, T2 off. Sebalik jika sinyal ouput B memberikan perintah on maka, T1 off, T2 on. Kemudian output-nya akan diteruskan menuju switch mosfet

\section{Switch Mosfet}

Pada rangkaian power supply ini, swicth MOSFET menggunakan konfigurasi Half-Bridge ,dengan konfigurasi ini mampu untuk mengkonversi besaran listrik dari searah menjadi besaran listrik bolak-balik berpulsa. Listrik bolak-balik berpulsa yang dihasilkan disearahkan dengan dioda fastrecovery dan output filter. Sehingga rangkaian ini termasuk dalam DC - DC konverter yang memanfaatkan topologi half-bridge konverter.Rangkaian ini terdari dari Half-Bridge MOSFET, transformator, dan output filter.

Ada beberapa tipe macam topologi konversi DC ke DC, karena tingkat kemudahan dan sedikitnya kerugian arus pada saat pensaklaran pada MOSFET. Urutan pensaklaran MOSFET M1, dan M2 adalah sebagai berikut:

1. Saat saklar M1 ON, maka saklar M2 akan OFF kemudian arus akan mengalir menuju trafo daya kumparan primer kemudian menuju trafo arus ke titik tengah dan ground..

2. Saat saklar M1 OFF, maka saklar M2 akan ON kemudian arus akan mengalir dari titik tengah menuju ke M2 melewati kumparan primer dan diteruskan ke ground.
Sehingga dengan kerja MOSFET yang saling bergantian maka pada kumparan kerja trafo daya akan mengalir arus bolak-balik (AC). Listrik bolak-balik yang menghasilkan tegangan $26 \mathrm{VAC}$, dengan frekuensi tinggi. Sehingga dibutuhkan penyearah. Penyearah ini berfungsi untuk menyearahkan gelombang pulsa menjadi searah. Rangkaian penyearah ini menggunakan dioda fast-recovery karena dianggap mampu bekerja pada frekuensi tinggi. Sedangkan kapasitor dengan tujuan untuk memblok frekuensi bocor dan mengurangi ripple yang terjadi setelah penyearahan. MOSFET yang digunakan pada Half-Bridge konverter ini adalah MOSFET tipe IRFZ44N. Ditinjau dari datasheet MOSFET IRFZ44N, MOSFET tipe ini mampu bekerja untuk pensaklaran pada frekuensi tinggi yang akan di aplikasikan untuk power supply switching.

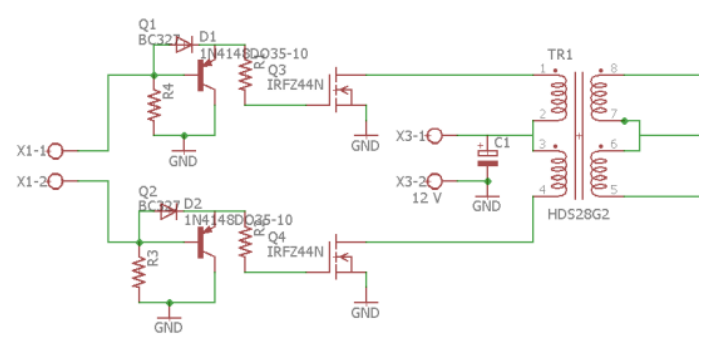

Gambar 7 Rangkaian Driver Mosfet dan Switch Mosfet

\section{Rangkaian Penyearah}

Listrik bolak-balik yang dihasilkan berupa pulsa hasil switching dari kombinasi MOSFET yang disusun secara Half-Bridge, dengan frekuensi tinggi dari output trafo. Sehingga dibutuhkan penyearah dan rangkian filter. Penyearah ini berfungsi untuk menyearahkan gelombang pulsa menjadi searah. Rangkaian penyearah ini menggunakan dioda fastrecovery karena dianggap mampu bekerja pada frekuensi tinggi. Sedangkan rangkaian filter terdiri dari kapasitor dengan tujuan untuk memblok frekuensi bocor dan mengurangi ripple yang terjadi setelah penyearahan,dioda yang digunakan yaitu dioda MUR1560 yang mampu bekerja pada frekuensi tinggi dengan batas arus yang cukup tinggi. Hasil penyerahan berupa tegangan DC berdenyut, sehingga perlu penambahan rangkaian filter. Rangkaian filter yang bertujuan untuk memperkecil ripple tegangan dan filter terhadap frekuensi tinggi, sehingga dihasilkan output tegangan DC

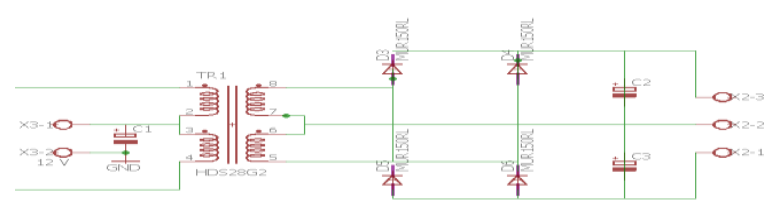

Gambar 8. Rangkaian Penyearah 


\section{PENGUKURAN DAN PENGUJIAN}

Pada pengukuran dan pengujian power supply inverter meliputi beberapa point yaitu pengukuran frekuensi switching yang dihasilkan, pengujian kestabilan tegangan dan pengujian efesiensi daya.

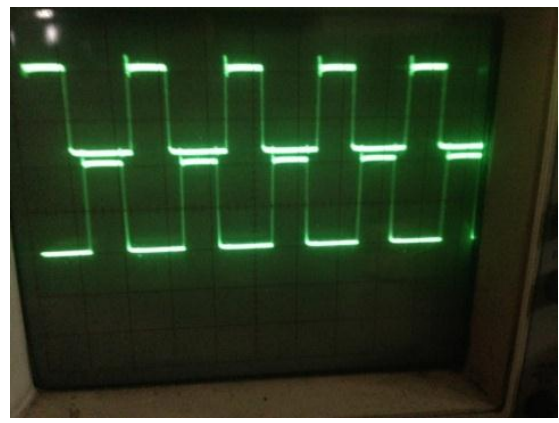

Gambar 9. Bentuk Gelombang Tegangan Keluaran IC TL494

\section{KESIMPULAN}

Dalam penelitian ini penulis mengambil beberapa kesimpulan sebagai berikut:

- Frekuensi yang dihasilkan dari TL494 yang digunakan untuk melakukan pensaklaran yaitu $94 \mathrm{KHz}$.

- Power supply inverter dapat digunakan untuk mensuplai amplifier audio yang memiliki daya maksimum $100 \mathrm{~W}$ dengan tegangan +/-26 V , 10 A.

- Semakin besar daya yang digunakan maka semakin besar pula drop tegangan pada keluaran inverter

\section{DAFTAR PUSTAKA}

1. Barkhordarian, V. Power MOSFET Basics. International Rectifier: California. E-book :www.aosmd.com. Didownload pada april 2016. Pukul 21.15 WIB.

2. Hermawan, H. Rancang Bangun Sistem Kendali High Frequency Induction Heating. Skripsi S1 Teknik Elektro. Jakarta: Universitas Indonesia.

3. Malvino . 1995. Prinsip-prinsip Elektronika Jakarta : Erlangga.

4. Maruitula, Edison. 2011. Rancang Bangun Flyaback Regulator Untuk Mencatu Sistem Pensaklaran IGBT pada Invereter. Skripsi S1 Teknik Elektro .Depok : Unversitas Indonesia.

5. Muis, Saludin. 2013. Perancangan Teori Dan Praktis Power Supply Jenis Switch Mode. Yogyakarta : Graha Ilmu.

6. Rasyid, Muhammad H. 1999. Elektronika Daya. Jakarta : PT Prenhallindo. 